\title{
Gene expression profiling of archival tongue squamous cell carcinomas provides sub-classification based on DNA repair genes
}

\author{
MATILDA RENTOFT ${ }^{1}$, GÖRAN LAURELL ${ }^{2}$, PHILIP JOHN COATES ${ }^{3}$, \\ BJÖRN SJÖSTRÖM ${ }^{2}$ and KARIN NYLANDER ${ }^{1}$
}

\begin{abstract}
${ }^{1}$ Department of Medical Biosciences/Pathology, Building 6M, 2nd floor, Umeå University, SE-901 85 Umeå; ${ }^{2}$ Department of Clinical Sciences/Otorhinolaryngology, Umeå University Hospital, SE-901 87 Umeå, Sweden;

${ }^{3}$ Division of Medical Sciences, University of Dundee, Ninewells Hospital and Medical School, Dundee, UK
\end{abstract}

Received June 4, 2009; Accepted July 10, 2009

DOI: 10.3892/ijo_00000450

\begin{abstract}
A subgroup of patients with squamous cell carcinoma of the head and neck (SCCHN) comprise young persons under the age of 40, who have not been heavily exposed to the classical risk factors, smoking and alcohol. The number of SCCHN in young adults, particularly tongue tumours, is increasing in several parts of the world. Here we employed a novel gene expression array methodology specifically developed for analysis of degraded RNA and investigated the expression of 502 cancer-related genes in archival paraffin-embedded SCCHN of the tongue from young $(\leq 40)$ and elderly patients $(\geq 50)$. Genes detected as de-regulated in tumours compared to non-malignant controls were in concordance with results from earlier studies of fresh frozen material. No genes were detected as significantly differentially expressed between young and old patients suggesting that the overall pathobiology of SCCHN is similar in young and old. Unsupervised clustering divided tumours into three groups, irrespective of age, where several differentially expressed DNA repair genes were a prominent separation factor. High levels of DNA repair genes associated with impaired therapeutic response to radiation, suggesting that DNA repair genes play a role in clinical outcome after radiotherapy.
\end{abstract}

\section{Introduction}

Squamous cell carcinoma of the head and neck (SCCHN) is historically a disease of middle-aged to elderly men and attributed to long-term use of tobacco and/or alcohol abuse $(1,2)$. The most common sites for oral squamous cell

Correspondence to: Matilda Rentoft, Department of Medical Biosciences/Pathology, Umeå University, Bldg 6M, 2nd floor, SE-901 85 Umeå, Sweden

E-mail: matilda.rentoft@medbio.umu.se

Key words: microaray, formalin-fixed paraffin-embedded, squamous cell carcinoma of the head and neck, tongue, young adults carcinoma (SCC) are tongue, floor of the mouth and lip. High biological and prognostic diversity has been seen between SCCHN tumours originating from different sites (3-5). Tumours of the tongue are reported to have a unique gene expression pattern making it possible to separate them from other tumours in the oral cavity (6), emphasizing the need for site-specific studies. An increase in SCCHN in young adults, particularly tumours affecting the tongue, has been reported from many parts of the world including Scandinavia (7-10). Young patients with SCCHN are less commonly associated with smoking and alcohol abuse, suggesting that there are other important factors governing the development of tongue tumours in young adults. Other aspects of the disease also differ between young and old patients, for example the male to female ratio is lower in the younger group (11). SCCHN has been described in some reports as being more aggressive in younger patients $(12,13)$, whereas other reports have not found any difference, or even seen better survival in young patients (14-16).

Primary treatment for SCC affecting the tongue consists of either surgery or combined surgery and radiotherapy. Due to the rather low five-year survival for this disease there is a need for markers that can guide the choice of therapy and/or predict outcome. Many candidate genes have been identified, including p53, cyclin D1 and epidermal growth factor receptor (EGFR) (17-19), but no factor has shown sufficient importance on its own and a multi-gene profile could thus be a better tool for identifying or predicting the course of SCCHN tumours. cDNA microarray techniques, which offer the opportunity to simultaneously study expression levels of a large number of genes, have proven useful for identifying tumour-specific gene expression profiles as well as for classifying subgroups of tumours (20-23).

The standard method for preserving tissue samples for clinical histopathological examination is fixation in formalin followed by embedding in paraffin (FFPE). A significant problem with FFPE samples for molecular studies is the low quality of RNA, which during fixation and storage is chemically modified and heavily degraded, making it resistant to reverse transcriptase reactions $(24,25)$. In recent years, methods for extracting and amplifying RNA from FFPE samples have 
been developed and expression studies using these samples are emerging $(26,27)$. Here we utilized a recently developed microarray technique for analysis of degraded RNA called cDNA-mediated annealing, selection, extension and ligation (DASL) $(28,29)$. Squamous cell carcinoma of the tongue from young ( $\leq 40$ years) and old ( $\geq 50$ years) patients were studied for expression of 502 selected cancer-related genes. The aims were to investigate the applicability of this technique for providing reproducible data from archival SCCHN samples collected at various times, to identify potential differences in the pathobiology of tongue tumours in young adults, and to identify genes that sub-classify these tumours and may act as potential prognostic biomarkers.

\section{Materials and methods}

Tissue. FFPE blocks from 27 patients with SCCHN of the tongue and from nine patients with non-malignant conditions from the same site were available for analysis. For one patient, two separate tumour biopsies were available $(24 \mathrm{~A}$ and 24B). Fourteen patients were considered young, 24-40 years of age, and 10 were considered old, 52-79 years of age. The mean age in the two groups was 33.9 and 67.4 years, respectively. Three patients (age 41, 42 and 46) did not fall into either of these groups but were included in the analysis of tumours irrespective of patient age. Descriptive data of all patients including smoking status, TNM and pCR (pathological complete remission) is summarized in Table I. Punch biopsies from the buccal mucosa of four healthy volunteers were used for comparison of RNA quality between fresh frozen tissue and FFPE samples. The tissue had been snap frozen in liquid nitrogen and stored at $-80^{\circ} \mathrm{C}$. The study was approved by the local Ethics Committee at Umeå University (dnr 01-057, dnr 08-003M and dnr 01-210).

RNA isolation and quality assessment. FFPE sample were cut into $5 \mu \mathrm{m}$ sections. Depending on the size of the sample, 3-20 sections were collected giving an approximate total area of $1 \mathrm{~cm}^{2}$. RNA was isolated using the High Pure RNA Paraffin Kit (Roche Diagnostics GmbH, Mannheim, Germany). In brief, sections were deparaffinised in xylene and lysed overnight in proteinase K. Solubilised nucleic acids were bound and washed three times in a filter tube before DNAse I treatment and a second round of washing. Purified RNA was eluted in nuclease-free water and stored at $-80^{\circ} \mathrm{C}$. The same protocol was used for the fresh frozen (FF) samples. However, instead of incubation in xylene these samples were cut into small pieces and homogenized by drilling (Black \& Decker). RNA concentration was measured using a nanodrop (ND1000 spectrophotometer) and RNA integrity assessed both by visualizing the size of the RNA on an Agilent 2100 bioanalyzer together with Agilent RNA 600 Nano kit (Agilent Technologies, Santa Clara, CA, USA) and by determining the amplification ability in a q-PCR reaction according to Illumina recommendations. q-PCR reactions were carried out using a Lightcycler ${ }^{\mathrm{TM}}$ with Lightcycler Fast Start DNA master SYBR-Green I kit (Roche Diagnostics $\mathrm{GmbH}$ ) according to the manufacturer's recommendations. RNA was also extracted from a number of cell lines (FaDu, U2OS, MCF-7, Saos-2, Raji, H1299 and SCC25) using TRIzol (Invitrogen, Carlsbad, CA, USA).
Table I. Clinical data.

\begin{tabular}{|c|c|c|c|c|c|}
\hline Case & Age & Sex & TNM & Smoking & $\mathrm{pCR}^{\mathrm{a}}$ \\
\hline 5 & 24 & $\mathrm{~F}$ & T2N0M0 & No & non-CR \\
\hline 25 & 27 & $\mathrm{M}$ & $\mathrm{T} 2 \mathrm{~N} 1 \mathrm{M} 0$ & No & $\mathrm{CR}$ \\
\hline 36 & 29 & $\mathrm{~F}$ & $\mathrm{~T} 2 \mathrm{~N} 2 \mathrm{aM} 0$ & Yes & non-CR \\
\hline 3 & 30 & $\mathrm{~F}$ & T3N0M0 & Yes & CR \\
\hline 24 & 30 & $\mathrm{M}$ & T2N0M0 & No & $\mathrm{CR}$ \\
\hline 26 & 31 & $\mathrm{~F}$ & $\mathrm{~T} 2 \mathrm{~N} 2 \mathrm{bM} 0$ & No & non-CR \\
\hline 32 & 34 & $\mathrm{M}$ & T2N0M0 & Yes & $\mathrm{CR}$ \\
\hline 29 & 36 & $\mathrm{M}$ & T2N0M0 & Yes & $\mathrm{CR}$ \\
\hline 13 & 38 & $\mathrm{~F}$ & T2N0M0 & Yes & $\mathrm{CR}$ \\
\hline 8 & 38 & $\mathrm{M}$ & T1N0M0 & Yes & $-^{b}$ \\
\hline 4 & 39 & $\mathrm{M}$ & T2N0M0 & No & non-CR \\
\hline 9 & 39 & $\mathrm{~F}$ & T2N0M0 & Yes & non-CR \\
\hline 35 & 40 & $\mathrm{~F}$ & T2N0M0 & Yes & $\mathrm{CR}$ \\
\hline 30 & 40 & $\mathrm{~F}$ & T3N0M0 & Yes & non-CR \\
\hline 28 & 41 & $\mathrm{M}$ & $\mathrm{T} 3 \mathrm{~N} 2 \mathrm{bM} 0$ & Yes & $\mathrm{CR}$ \\
\hline 7 & 42 & $\mathrm{M}$ & T1N0M0 & No & $\mathrm{CR}$ \\
\hline 33 & 46 & $\mathrm{M}$ & T1N0M0 & No & $\mathrm{CR}$ \\
\hline 14 & 52 & $\mathrm{~F}$ & T4N2cM0 & No & $-^{\mathrm{e}}$ \\
\hline 11 & 58 & $\mathrm{M}$ & $\mathrm{T} 3 \mathrm{~N} 2 \mathrm{bM} 0$ & Yes & $\mathrm{CR}$ \\
\hline 34 & 62 & $\mathrm{M}$ & T1N0M0 & Yes & $-^{\mathrm{b}}$ \\
\hline 10 & 64 & $\mathrm{M}$ & T1N0M0 & No & $-^{c}$ \\
\hline 31 & 65 & $\mathrm{~F}$ & T2N0M0 & No & $-^{\mathrm{d}}$ \\
\hline 2 & 69 & $\mathrm{~F}$ & T2NOM0 & No & $\mathrm{CR}$ \\
\hline 1 & 74 & $\mathrm{M}$ & T2N0M0 & Yes & $\mathrm{CR}$ \\
\hline 6 & 74 & $\mathrm{M}$ & T3N2bM0 & Yes & non-CR \\
\hline 12 & 77 & $\mathrm{~F}$ & $\mathrm{~T} 2 \mathrm{~N} 1 \mathrm{M} 0$ & No & $\mathrm{CR}$ \\
\hline 27 & 79 & $\mathrm{M}$ & T2N0M0 & Yes & $-{ }^{f}$ \\
\hline
\end{tabular}

aPathological complete remission (pCR) after preoperative radiotherapy and surgery; - data not available due to: ${ }^{b}$ post operative radio therapy, ${ }^{\mathrm{c}}$ surgery only, ${ }_{\mathrm{d}}^{\mathrm{d}}$ radiotherapy only, ${ }^{\mathrm{e}}$ no treatment, ${ }^{\mathrm{f}}$ died during radiation therapy.

Microarray. Gene expression profiles were achieved using the DASL assay which is developed specifically for analysis of partially degraded RNA. The Illumina DASL Human Cancer Panel gene set (Illumina, San Diego, CA, USA) targeting 502 cancer-related genes was used. mRNA was converted into biotinylated cDNA and annealed to pairs of gene-specific query oligonucleotides containing universal PCR primer landing sites and a hybridization address sequence. The product was then washed and correctly annealed oligonucleotides were extended and ligated. Amplification was carried out with fluorescently labelled PCR primers and the product was hybridized to an Illumina Sentrix universal Array Matrix. This platform is a fibre-optic assembly containing 96 individual arrays and all samples were run in duplicate. Illumina BeadArray Reader 500 was used for scanning the arrays.

Data analysis. Array data were normalized using the cubiq spline algorithm included in the BeadStudio software 
provided by Illumina. Internal BeadStudio controls for hybridization, background signal and contamination were used for assessing the quality of the arrays. Genes were considered detected if the detection P-value was lower than 0.01 . Genes not detected in any of the arrays were excluded. Simple linear regression was used to investigate the technical reproducibility of the arrays. Expression values were exported from BeadStudio and further processed and visualized using Microsoft Excel and MultiExperiment Viewer, MeV4.0 (http://www.tm4.org). Differentially expressed genes were identified using two statistical tests, t-test and SAM (Significance Analysis of Microarrays) (30), and using fold-change calculations. P-values from t-tests were corrected for multiple testing by Bonferroni correction and the significance threshold was set at $\mathrm{P}<0.05$. Default parameters were selected for SAM calculations. Before fold-change calculations, expression values were truncated to a value of 200 (all values $<200$ were set to 200) to avoid selection of low-intensity genes which from replicate analysis were found to be unreliable. All samples in a group were considered biological replicates during analysis and no information about gene expression for separate samples were taken into consideration. Clustering of samples was performed by unsupervised hierarchical clustering using Euclidian distance measurements.

Quantitative real-time PCR analysis. Because of the limited amount of RNA, a selection of tumour samples and control samples for each of four genes were used for confirmation of microarray data by q-PCR. RNA from tissue and cell lines were processed the same way. First strand cDNA was synthesised using Cloned AMV First-Strand cDNA Synthesis kit (Invitrogen) with 200 ng of RNA and random primers in a $20 \mu 1$ reaction mixture. cDNA $(1 \mu 1)$ reaction was then subsequently used as template for amplification of TUBA6 (house-keeping gene), EGFR, SERPINE1/PAI-1, BCL2AI and $B R C A 2$. The q-PCR reaction was carried out in a $20 \mu \mathrm{l}$ reaction using IQ SYBR-Green Supermix (BioRad, Hercules, CA, USA) according to the manufacturer's recommendations. The gene specific product was kept under $100 \mathrm{bp}$ to optimize conditions for amplification of degraded RNA (31). All products were also designed to cross an intron/exon junction to avoid amplification of genomic DNA. Primer sequences were as follows: TUBA6 5'CCGGGCAGTGTTTGTAGACT-3' and 5'-TTGCCTGTG ATGAGTTGCTC-3'; EGFR 5'-CGTCGTCCATGTCTTCT TCA-3' and 5'-CAGCGCTACCTTGTCATT-3'; SERPINE 5'-CAGGAAGCCCCTAGAGAACC-3' and 5'-GTGGAG AGGCTCTTGGTCTG-3'; BRCA2 5'-GAGAAGCTGCAA GTCATGGAT-3' and 5'-CATTTGGCATTGACTTTCCA-3'; BCL2A1 5'-GTTGCGGAGTTCATAATGAATAAC-3' and 5'-CCAGCCAGATTTAGGTTCAAAC-3'. The reaction was carried out in an IQ5 real-time detection system (BioRad) using a two-step reaction with an annealing and extension time and temperature of $30 \mathrm{~s}$ at $60^{\circ} \mathrm{C}$. All genes were normalized to TUBA6 expression levels and samples were run in duplicate or triplicate.

Immunohistochemistry. Two gene products (EGFR and BCL2A1) were also analysed using immunohistochemistry. Sections from the same FFPE samples used for the q-PCR confirmation were immunostained using an EGFR-specific antibody (Dako, Glostrup, Denmark) and a BCL2A1-specific antibody (Abcam, Cambridge, UK) both diluted 1:50. EGFR samples were pre-treated with proteinase 1 and BCL2A1 samples with citrate or EDTA and staining was performed using a Ventana staining machine and reagents according to the supplier's recommendations.

Estimation of degree of inflammation. Degree of inflammation in tumour samples was estimated by the number of infiltrating leukocytes and divided into three classes designated as weak, moderate and strong by an experienced oral pathologist $(\mathrm{KN})$.

Complete pathological remission ( $p C R)$. The majority of the patients $(n=21)$ were treated with preoperative radiation and surgery. Treatment for the remaining cases $(n=6)$ is described in Table I. Response to preoperative radiotherapy was evaluated by analysing the presence of viable tumour cells in the surgical specimen and classified as complete pathological remission (pCR) or non-complete pathological remission (non-pCR) as described before $(32,33)$.

\section{Results}

RNA extraction and integrity. Quality of the RNA extracted from the 37 FFPE blocks was assessed by capillary electrophoresis (2001 BioAnalyzer; Agilent, Santa Clara, USA) and by monitoring amplification of the ribosomal protein L13A (RPL13A) using RT-qPCR. Ribosomal RNA was not clearly visible from micro-capillary electrophoresis and a trend towards higher degradation of RNA with storage time was seen (Fig. 1A). In the q-PCR reaction, amplification of RNA from FFPE and fresh frozen (FF) tissue (using an average of four frozen samples) was compared. A difference of more than twelve cycles between the two was set as a cut-off for inadequate RNA quality (Illumina recommendations). Cycle numbers for FFPE samples were 3-10 cycles higher than for FF samples. The age of the paraffin block could only explain a very small part of that variation $\left(r^{2}=0.18\right.$ using simple linear regression, Fig. 1B). This is not surprising as the modifications caused by the formaldehyde during tissue fixation, and not the degradation of the RNA, has been shown to be the strongest limiting factor for the q-PCR reaction $(24,25)$. Thus, fixation time and/or delay in fixation are probably the main factors preventing the use of stored tissue samples, although prolonged storage also slightly impairs RNA quality.

Array quality. All samples passed the RNA quality control and were analysed in duplicate, allowing analysis of all 74 samples in parallel. All arrays showed good hybridisation, no contamination and low background signal (internal controls), but four patients $(2,7,8$ and 16) were excluded due to low replicate reproducibility, observed as low correlation indices $\left(\mathrm{r}^{2}<0.8\right)$ or failure to cluster together using hierarchical clustering. The remaining samples had good reproducibility with correlation indices $\left(\mathrm{r}^{2}\right)$ as high as 0.98 (data not shown). Eighteen genes were not detected in any of the arrays. Data from the remaining 484 genes were therefore used throughout the analysis. 
Table II. Genes significantly differentially expressed between tumour samples and normal tissue using two statistical tests, t-test and SAM.

\begin{tabular}{|c|c|c|c|}
\hline Gene symbol & Accession number & $\mathrm{P}$-value ${ }^{\mathrm{a}}$ & Bonferroni $^{\mathrm{b}}$ \\
\hline$B C L 2 A 1$ & NM_004049.2 & $8.1 \mathrm{E}-10$ & 4.0E-07 \\
\hline ICAMI & NM_000201.1 & $1.1 \mathrm{E}-08$ & $5.7 \mathrm{E}-06$ \\
\hline$M M P 9$ & NM_004994.1 & $1.7 \mathrm{E}-08$ & $8.4 \mathrm{E}-06$ \\
\hline$T G F B 1$ & NM_000660.1 & $1.8 \mathrm{E}-08$ & 8.8E-06 \\
\hline$I L I R N$ & NM_173843.1 & $1.9 \mathrm{E}-08$ & $9.4 \mathrm{E}-06$ \\
\hline$L T A$ & NM_000595.2 & 3.7E-08 & $1.9 \mathrm{E}-05$ \\
\hline PLAUR & NM_002659.1 & 3.8E-08 & 1.9E-05 \\
\hline$S K I$ & NM_003036.1 & $6.2 \mathrm{E}-08$ & $3.1 \mathrm{E}-05$ \\
\hline$A P C$ & NM_000038.2 & $6.3 \mathrm{E}-08$ & $3.1 \mathrm{E}-05$ \\
\hline$R A P 2 A$ & NM_021033.3 & $6.9 \mathrm{E}-08$ & $3.4 \mathrm{E}-05$ \\
\hline$M M P 7$ & NM_002423.2 & 9.3E-08 & $4.6 \mathrm{E}-05$ \\
\hline$M M P 1$ & NM_002421.2 & $1.0 \mathrm{E}-07$ & $5.2 \mathrm{E}-05$ \\
\hline ARHA & NM_001664.1 & $1.9 \mathrm{E}-07$ & $9.4 \mathrm{E}-05$ \\
\hline$D S P$ & NM_004415.1 & $2.7 \mathrm{E}-07$ & $1.3 \mathrm{E}-04$ \\
\hline$P M L$ & NM_033240.1 & $3.0 \mathrm{E}-07$ & $1.5 \mathrm{E}-04$ \\
\hline PRKR & NM_002759.1 & $3.4 \mathrm{E}-07$ & $1.7 \mathrm{E}-04$ \\
\hline$V A V 2$ & NM_003371.1 & $3.8 \mathrm{E}-07$ & $1.9 \mathrm{E}-04$ \\
\hline$A L O X 12$ & NM_000697.1 & $4.6 \mathrm{E}-07$ & $2.3 \mathrm{E}-04$ \\
\hline PTHLH & NM_002820.1 & 4.7E-07 & $2.3 \mathrm{E}-04$ \\
\hline$B A G 1$ & NM_004323.2 & $6.2 \mathrm{E}-07$ & $3.1 \mathrm{E}-04$ \\
\hline$T F D P 1$ & NM_007111.3 & $6.4 \mathrm{E}-07$ & $3.2 \mathrm{E}-04$ \\
\hline$M M P 3$ & NM_002422.2 & 8.0E-07 & $4.0 \mathrm{E}-04$ \\
\hline$A R H H$ & NM_004310.1 & $8.1 \mathrm{E}-07$ & $4.0 \mathrm{E}-04$ \\
\hline$M A D$ & NM_002357.1 & $1.0 \mathrm{E}-06$ & $5.1 \mathrm{E}-04$ \\
\hline FER & NM_005246.1 & $1.1 \mathrm{E}-06$ & $5.6 \mathrm{E}-04$ \\
\hline RAD50 & NM_005732.2 & $1.1 \mathrm{E}-06$ & $5.6 \mathrm{E}-04$ \\
\hline$T N F$ & NM_000594.2 & $1.2 \mathrm{E}-06$ & $5.9 \mathrm{E}-04$ \\
\hline$E 2 F 3$ & NM_001949.2 & $1.2 \mathrm{E}-06$ & $6.2 \mathrm{E}-04$ \\
\hline ILS & NM_000584.2 & $1.5 \mathrm{E}-06$ & $7.5 \mathrm{E}-04$ \\
\hline KRAS2 & NM_004985.3 & $1.5 \mathrm{E}-06$ & 7.7E-04 \\
\hline PTK7 & NM_002821.3 & $2.0 \mathrm{E}-06$ & $1.0 \mathrm{E}-03$ \\
\hline$O S M$ & NM_020530.3 & 2.3E-06 & $1.1 \mathrm{E}-03$ \\
\hline$M X I 1$ & NM_005962.2 & $2.7 \mathrm{E}-06$ & $1.3 \mathrm{E}-03$ \\
\hline TGFBR3 & NM_003243.1 & $3.2 \mathrm{E}-06$ & $1.6 \mathrm{E}-03$ \\
\hline$H C K$ & NM_002110.2 & $3.5 \mathrm{E}-06$ & $1.7 \mathrm{E}-03$ \\
\hline$C S F 3 R$ & NM_156039.2 & $4.5 \mathrm{E}-06$ & $2.2 \mathrm{E}-03$ \\
\hline CXCL9 & NM_002416.1 & $5.1 \mathrm{E}-06$ & $2.6 \mathrm{E}-03$ \\
\hline CTNNA1 & NM_001903.1 & $5.2 \mathrm{E}-06$ & $2.6 \mathrm{E}-03$ \\
\hline$R A F 1$ & NM_002880.1 & $5.3 \mathrm{E}-06$ & $2.6 \mathrm{E}-03$ \\
\hline$D C N$ & NM_133503.1 & $5.8 \mathrm{E}-06$ & $2.9 \mathrm{E}-03$ \\
\hline$D L E U 1$ & NM_005887.1 & $5.8 \mathrm{E}-06$ & $2.9 \mathrm{E}-03$ \\
\hline IRFI & NM_002198.1 & $6.2 \mathrm{E}-06$ & $3.1 \mathrm{E}-03$ \\
\hline STAT1 & NM_007315.2 & 7.2E-06 & $3.6 \mathrm{E}-03$ \\
\hline EVI2A & NM_014210.1 & $7.6 \mathrm{E}-06$ & $3.8 \mathrm{E}-03$ \\
\hline$B A R D 1$ & NM_000465.1 & $9.5 \mathrm{E}-06$ & $4.8 \mathrm{E}-03$ \\
\hline $\mathrm{CCNH}$ & NM_001239.2 & $1.1 \mathrm{E}-05$ & $5.4 \mathrm{E}-03$ \\
\hline$D D X 6$ & NM_004397.3 & $1.2 \mathrm{E}-05$ & $5.8 \mathrm{E}-03$ \\
\hline VIL2 & NM_003379.3 & $1.2 \mathrm{E}-05$ & $5.9 \mathrm{E}-03$ \\
\hline
\end{tabular}

Table II. Continued.

\begin{tabular}{|c|c|c|c|}
\hline Gene symbol & Accession number & $\mathrm{P}$-value $\mathrm{a}^{\mathrm{a}}$ & Bonferroni $^{\mathrm{b}}$ \\
\hline MAPK14 & NM_139012.1 & $1.3 \mathrm{E}-05$ & $6.7 \mathrm{E}-03$ \\
\hline$M S F$ & NM_006640.2 & $1.6 \mathrm{E}-05$ & 7.9E-03 \\
\hline$P B X 1$ & NM_002585.1 & $2.0 \mathrm{E}-05$ & $1.0 \mathrm{E}-02$ \\
\hline$E L L$ & NM_006532.1 & 2.3E-05 & $1.2 \mathrm{E}-02$ \\
\hline FZD7 & NM_003507.1 & $2.6 \mathrm{E}-05$ & $1.3 \mathrm{E}-02$ \\
\hline$N F K B 2$ & NM_002502.2 & $3.3 \mathrm{E}-05$ & $1.6 \mathrm{E}-02$ \\
\hline$W R N$ & NM_000553.2 & $3.4 \mathrm{E}-05$ & $1.7 \mathrm{E}-02$ \\
\hline TNFRSF5 & NM_152854.1 & $3.4 \mathrm{E}-05$ & $1.7 \mathrm{E}-02$ \\
\hline TYRO3 & NM_006293.2 & $4.3 \mathrm{E}-05$ & $2.1 \mathrm{E}-02$ \\
\hline$C D K 7$ & NM_001799.2 & $4.5 \mathrm{E}-05$ & $2.2 \mathrm{E}-02$ \\
\hline$C A S P 2$ & NM_032984.1 & 4.9E-05 & $2.5 \mathrm{E}-02$ \\
\hline$E R B B 3$ & NM_001982.1 & $5.2 \mathrm{E}-05$ & $2.6 \mathrm{E}-02$ \\
\hline$P X N$ & NM_002859.1 & $5.2 \mathrm{E}-05$ & $2.6 \mathrm{E}-02$ \\
\hline$I T G B 1$ & NM_033669.1 & 7.9E-05 & $4.0 \mathrm{E}-02$ \\
\hline$B A K 1$ & NM_001188.2 & $8.0 \mathrm{E}-05$ & 4.0E-02 \\
\hline$C D C 25 B$ & NM_021873.1 & $8.1 \mathrm{E}-05$ & 4.0E-02 \\
\hline PIM1 & NM_002648.2 & $9.4 \mathrm{E}-05$ & 4.7E-02 \\
\hline
\end{tabular}

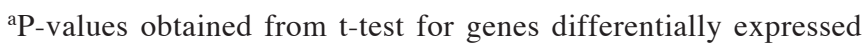
both using t-test and SAM; ${ }^{b}$ Bonferoni corrected P-values for multiple testing.

Genes differentially expressed in tumour samples. Unsupervised hierarchical clustering was performed in order to visualize gene expression data and identify sample groups that share similar overall gene expression patterns (34). As seen in the resulting dendogram, replicates clustered as pairs at the shortest distance and the two biopsies originating from the same patient (24A and B) formed a tight four-sample cluster (Fig. 1C). Overall, samples divided into three large clusters with one group containing all non-malignant control samples (group C) and two groups comprising samples from cancer patients (group 1 and 2). One tumour biopsy (sample 9) clustered together with the control samples. This was a highly differentiated tumour with a high content of tumour tissue in the sample analysed.

Differences in gene expression profiles between cancer and control samples were analyzed using t-test and SAM (significance analysis of microarrays), resulting in a set of 126 significantly differentially expressed genes. Sixty-five genes were found using both tests (Table II), including antiapoptotic (BCL2Al), matrix remodelling (MMPs), cell proliferation/growth $(C D C 25 B, T G F B 1, M A D)$, inflammation $(I L 8, T N F)$ and cell migration (ITGB1, ICAM1) genes.

Differences between tumours and controls were also assessed by studying fold-changes. Sixty-two genes had a mean expression value more than 2-fold up- or downregulated in cancer samples as compared to non-malignant controls (Table III). Ten genes, of which five were matrix metalloproteinases (MMP1, MMP3, MMP7, MMP9 and $M M P 10)$, had an increased expression of more than 5-fold. Secreted phosphoprotein 1 (SPP1) had the highest induction 
A

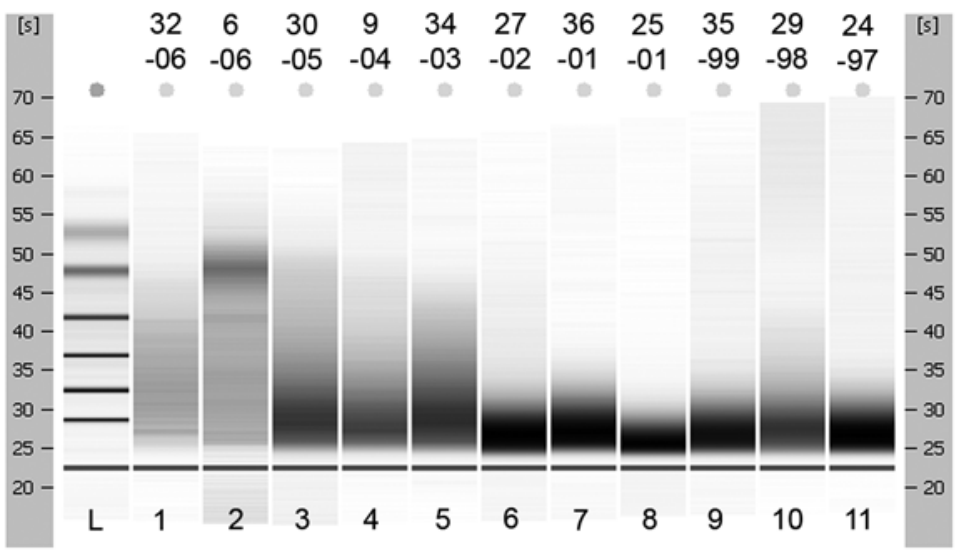

B

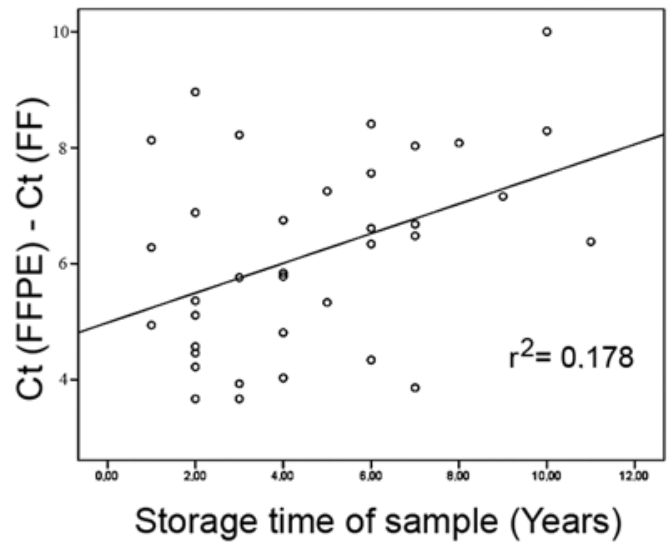

C

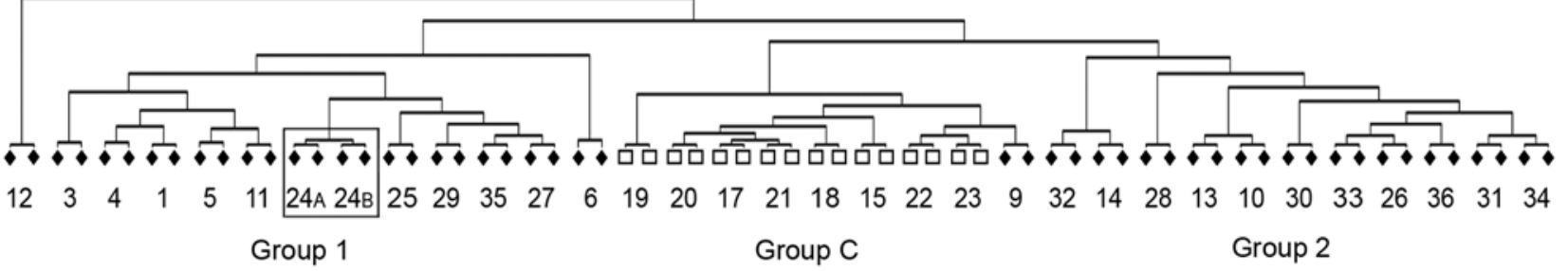

Figure 1. Evaluation of RNA quality from FFPE material. (A) RNA integrity was visualized using micro-capillary electrophoresis resulting in a gel-like image. The sample number and year of surgical removal of the sample are indicated above each lane. (B) Correlation between age of sample and performance in q-PCR reaction was evaluated in a scatter plot. The Ct-value for each FFPE sample was compared to an averaged Ct-value from four fresh-frozen (FF) samples. (C) Hierarchical cluster analysis of gene expression analysis using DASL microarray. Material from all patients was analysed in duplicate, forming small two sample clusters at the shortest distance. Squares represent control samples and diamonds tumour samples. Samples, 24A and B, encircled in the picture, are two separate biopsies from the same patient.

with an 18-fold mean difference between cancer and control samples. These findings are in agreement with earlier studies using fresh frozen tissue (35).

Comparing the lists of genes showing statistical significance and those that are more than 2-fold different, only 25 genes fulfil both criteria, reflecting the differences in approach: While the statistical tests identify consistent changes, the 2-fold calculations identify genes that are highly over- or under-expressed in only a fraction of patients.

Confirmation of array data. To confirm microarray results two genes with high expression (EGFR and $P A I-1)$ and two genes with low expression (BCL2A1 and BRCA2), according to the array, were analysed using quantitative real-time RTPCR in a selection of tumours $(n=4-6)$ and controls $(n=3-4)$. All expressions were normalized to TUBA6 which according to GeNorm calculations is stably expressed across cancerous and normal head and neck tissue (own unpublished data). Similar results as for the microarray experiment were obtained using q-RT-PCR (Fig. 2).

EGFR was also studied at the protein level, using immunohistochemistry, in the same samples as was confirmed using q-PCR. Tumours and normal tissue showed a strong staining of EGFR predominantly in the cell membrane. The three tumours over-expressing EGFR at the mRNA level had the strongest staining intensity (Fig. 3). Protein expression of
BCL2A1 could not be studied by immunochemistry due to inconsistent results and non-specific antibody binding could not be ruled out.

Fraction of infiltrating immune cells. BCL2A1 was first described to be specific to cells of haematological origin and it was therefore of interest to clarify if the over expression of $B C L 2 A 1$ seen in tongue tumours was due to inflammatory or cancer cells. Levels of BCL2A1 mRNA varied in cancer samples with some showing high up-regulation while others only had a slight increase compared to controls. To compare this to the degree of inflammation the number of inflammatory cells was estimated in a selection of samples $(n=8)$, showing either high or low BCL2Al expression. No correlation was seen between degree of inflammation and levels of $B C L 2 A 1$. A number of cancer cell lines were also analysed for expression of BCL2Al using q-PCR. BCL2Al was detectable in head and neck cancer derived cell lines (SCC25, FaDu) as well as in other cell lines (U2OS, MCF-7, Saos-2, Raji). H1229 cells were negative for BCL2A1 expression while Raji cells derived from a patient with Burkitt's lymphoma showed very high expression of BCL2AI (data not shown).

Young adults compared to older patients. To make data comparable to earlier studies, patients under the age of 40 
Table III. Genes $\geq 2$-fold up- or down-regulated in tumour samples compared to normal tissues.

\begin{tabular}{|c|c|c|c|c|c|}
\hline & \\
\hline \multirow{2}{*}{ Gene symbol } & \multirow{2}{*}{ Accession number } & \multirow{2}{*}{ Avg. fold-change } & Gene symbol & Accession number & Avg. fold-change \\
\hline & & & & & \\
\hline$S P P 1$ & NM_000582.2 & 18.3 & $D L C 1$ & NM_024767.2 & -2.1 \\
\hline$M M P 9$ & NM_004994.1 & 15.7 & $T G F B R 3$ & NM_003243.1 & -2.1 \\
\hline$M M P 1$ & NM_002421.2 & 13.2 & $M Y B$ & NM_005375.1 & -2.1 \\
\hline$M M P 3$ & NM_002422.2 & 10.8 & NTRK3 & NM_002530.1 & -2.2 \\
\hline IL8 & NM_000584.2 & 9.7 & $A R$ & NM_000044.2 & -2.3 \\
\hline$M M P 7$ & NM_002423.2 & 8.5 & CTNNAI & NM_001903.1 & -2.3 \\
\hline MMP10 & NM_002425.1 & 6.4 & $B A R D 1$ & NM_000465.1 & -2.4 \\
\hline CXCL9 & NM_002416.1 & 6.2 & $A B C B 1$ & NM_000927.2 & -2.4 \\
\hline ILI1 & NM_000641.2 & 5.7 & $D L E U 1$ & NM_005887.1 & -2.5 \\
\hline$B C L 2 A 1$ & NM_004049.2 & 5.4 & TYRO3 & NM_006293.2 & -2.5 \\
\hline$O S M$ & NM_020530.3 & 4.8 & $A L O X 12$ & NM_000697.1 & -4.3 \\
\hline$L T A$ & NM_000595.2 & 4.8 & $H L F$ & NM_002126.3 & -4.6 \\
\hline PTHLH & NM_002820.1 & 4.7 & \multirow{11}{*}{\multicolumn{3}{|c|}{$\begin{array}{l}\text { were considered young adults in this study }(7-10,36) \text {. } \\
\text { Statistical analysis using both t-test and SAM did not identify } \\
\text { any significantly differentially expressed genes between } \\
\text { young adults and older patients, indicating no consistent } \\
\text { changes. A few samples in one of the groups showing high } \\
\text { up- or down-regulation lead to three genes being detected as } \\
\text { 2-fold differentially expressed between young and old } \\
\text { SCCHN patients (BRCA2,FGFR } 2 \text { and } R A R B) \text {. }\end{array}$}} \\
\hline$T G F B 1$ & NM_000660.1 & 4.3 & & & \\
\hline CSF2 & NM_000758.2 & 3.9 & & & \\
\hline$T N F$ & NM_000594.2 & 3.9 & & & \\
\hline FOLRI & NM_016724.1 & 3.8 & & & \\
\hline SERPINE1 & NM_000602.1 & 3.6 & & & \\
\hline$E 2 F 3$ & NM_001949.2 & 3.4 & & & \\
\hline MYBL2 & NM_002466.2 & 3.4 & & & \\
\hline$L C K$ & NM_005356.2 & 3.2 & & & \\
\hline$C D K N 2 A$ & NM_058196.1 & 2.8 & & & \\
\hline IL6 & NM_000600.1 & 2.8 & & & \\
\hline TNFSF 8 & NM_001244.2 & 2.7 & \multirow{19}{*}{\multicolumn{3}{|c|}{$\begin{array}{l}\text { Hierarchical clustering of cancer patients. As mentioned } \\
\text { above, upon unsupervised hierarchical clustering, samples } \\
\text { from cancer patients divided into two large clusters, irres- } \\
\text { pective of age (group } 1 \text { and } 2 \text { ). When examining group } 1 \\
\text { closer, it further divided into two smaller groups } 1 \mathrm{~A} \text { (n=6) } \\
\text { and } 1 \mathrm{~B} \text { (n=5) (Fig. 4). Cluster } 1 \mathrm{~A} \text { was most distinct from the } \\
\text { other clusters regarding number of significantly differen- } \\
\text { tially expressed genes. Using SAM statistics, } 30 \text { genes were } \\
\text { differentially expressed between group } 1 \mathrm{~A} \text { and the other } \\
\text { tumour samples. Using a } 2 \text {-fold filter the number of genes } \\
\text { decreased to } 16 \text { [Table IV (A)]. Interestingly, four of these } \\
16 \text { genes were up-regulated DNA repair genes (BRCA2, } \\
X R C C 2, B L M \text { and } R E C Q L \text { ). Group } 1 \mathrm{~B} \text { on the other hand had } \\
15 \text { differentially expressed genes compared to the other } \\
\text { tumour samples and four of these were }>2 \text {-fold up- or down- } \\
\text { regulated [Table IV (B)]. Three of these four genes were } \\
\text { down-regulated DNA repair genes (BARD1, CCNH and } \\
\text { FANCG). In group } 2, P T G S 2 / C O X-2, L C N 2 \text { and SERPINE1 } \\
\text { were significantly changed in SAM calculations and showed } \\
\text { an induction or reduction of at least } 2 \text {-fold [Table IV (C)]. }\end{array}$}} \\
\hline CSF3 & NM_172219.1 & 2.7 & & & \\
\hline НОХА9 & NM_152739.2 & 2.7 & & & \\
\hline CSF3R & NM_156039.2 & 2.6 & & & \\
\hline$H C K$ & NM_002110.2 & 2.6 & & & \\
\hline$I C A M I$ & NM_000201.1 & 2.5 & & & \\
\hline$I L I B$ & NM_000576.2 & 2.4 & & & \\
\hline$A R H H$ & NM_004310.1 & 2.4 & & & \\
\hline PTPRH & NM_002842.1 & 2.2 & & & \\
\hline$D A P K 1$ & NM_004938.1 & 2.2 & & & \\
\hline$C D C 25 B$ & NM_021873.1 & 2.2 & & & \\
\hline$L I F$ & NM_002309.2 & 2.1 & & & \\
\hline BIRC3 & NM_182962.1 & 2.1 & & & \\
\hline CEACAMI & NM_001712.2 & 2.1 & & & \\
\hline$E R C C 2$ & NM_000400.1 & 2.1 & & & \\
\hline$C D H 11$ & NM_001797.2 & 2.0 & & & \\
\hline$B C L 2$ & NM_000657.1 & 2.0 & & & \\
\hline$B M P 4$ & NM_001202.2 & 2.0 & & & \\
\hline TERT & NM_198255.1 & 2.0 & & & \\
\hline BTK & NM_000061.1 & 2.0 & \multirow{7}{*}{\multicolumn{3}{|c|}{$\begin{array}{l}\text { Viable cells in surgery specimens after radiation therapy. } \\
\text { Overall } 21 \text { of the } 27 \text { patients in this study completed preoper- } \\
\text { ative radiation therapy and out of these } 67 \% \text { showed complete } \\
\text { pathological response (Table I). Group } 1 \mathrm{~A} \text {, characterized by } \\
\text { over-expression of DNA repair genes had three of six patients } \\
\text { with a pCR }(50 \%) \text {, while all five patients in group } 1 \mathrm{~B} \text { with } \\
\text { down-regulated DNA repair genes showed complete patho- } \\
\text { logical remission }(100 \%) \text {. }\end{array}$}} \\
\hline$N F K B 2$ & NM_002502.2 & 2.0 & & & \\
\hline PTGS2 & NM_000963.1 & 2.0 & & & \\
\hline$L C N 2$ & NM_005564.2 & -2.0 & & & \\
\hline$F G F 12$ & NM_004113.3 & -2.0 & & & \\
\hline PNUTL1 & NM_002688.2 & -2.0 & & & \\
\hline IGFBP5 & NM_000599.1 & -2.1 & & & \\
\hline
\end{tabular}

Table III. Continued.

were considered young adults in this study $(7-10,36)$. Statistical analysis using both t-test and SAM did not identify changes. A few samples in one of the groups showing high up- or down-regulation lead to three genes being detected as 2 -fold differentially expressed between young and old Hierarchical clustering of cancer patients. As mentioned above, upon unsupervised hierarchical clustering, samples from cancer patients divided into two large clusters, irrespective of age (group 1 and 2). When examining group 1 closer, it further divided into two smaller groups 1A $(\mathrm{n}=6)$ tially expressed genes. Using SAM statistics, 30 genes were differentially expressed between group 1A and the other tumour samples. Using a 2-fold filter the number of genes we $X R C C 2, B L M$ and $R E C Q L$ ). Group $1 \mathrm{~B}$ on the other hand had 15 differentially expressed genes compared to the other tumour samples and four of these were $>2$-fold up- or downregulated [Table IV (B)]. Three of these four genes were FANCG). In group 2, PTGS2/COX-2, LCN2 and SERPINEI were significantly changed in SAM calculations and showed Viable cells in surgery specimens after radiation therapy. Overall 21 of the 27 patients in this study completed preoperative radiation therapy and out of these $67 \%$ showed complete pathological response (Table I). Group 1A, characterized by over-expression of DNA repair genes had three of six patients down-regulated DNA repair genes showed complete pathological remission $(100 \%)$ 
EGFR

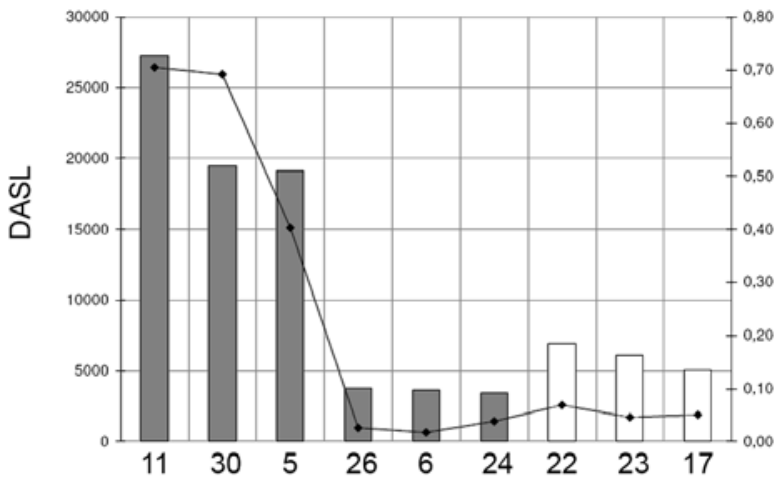

BRCA2

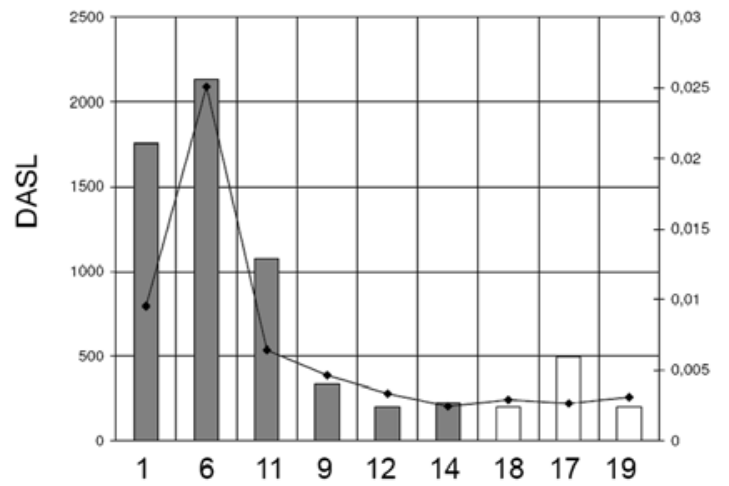

SERPINE

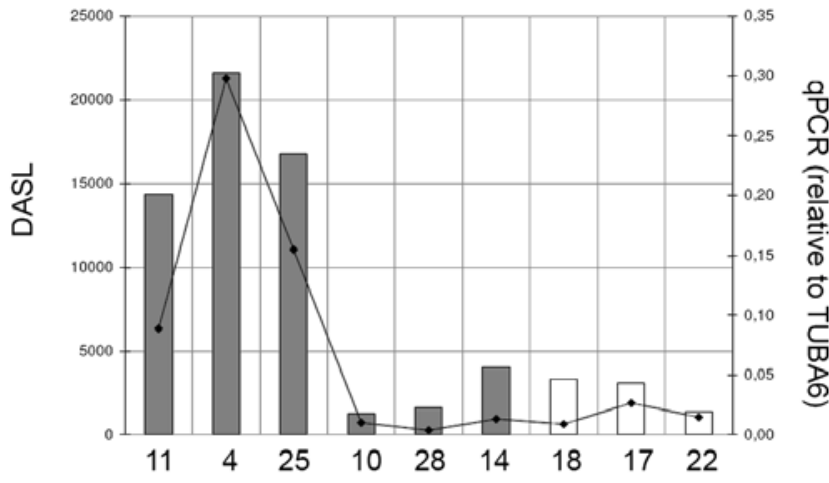

BCL2A1

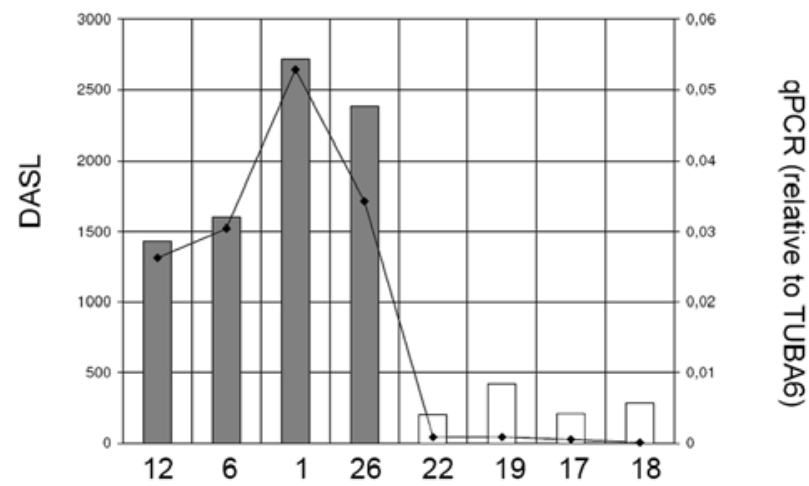

Figure 2. Confirmation of array data using q-PCR. Four genes representing high- and low-expressed genes, according to the array, were amplified using quantitative real-time PCR. DASL data are shown as bars while qPCR data are represented by a line. Tumours are coloured grey and control tissue white. Due to limited amount of material, genes were analyzed in only a selection of samples. EGFR, BRCA2 and SERPINE1, which showed over-expression in a fraction of the tumour samples, were analyzed in three tumour samples over-expressing the gene (1-3), three tumour samples not over-expressing the gene (4-6) and three control samples (7-9). BCL2A1 showing a more general over-expression in most tumour samples was analyzed in four random tumour samples (1-4) and four controls (5-8). All expression values were normalized to the internal control gene TUBA6.

\section{Discussion}

In this study we analyzed gene expression in formalin-fixed paraffin-embedded samples from SCC and benign control tissue from the tongue. FFPE samples are commonly available but contain highly degraded RNA. Using the DASL methodology, many of the genes identified as differentially expressed in cancer samples were similar to those previously identified from frozen samples i.e. TGFB1, SPP1, STAT-1, CSF 2/3, PLAUR, MMP and PTGS2 (COX-2) (35,37-39). EGFR is commonly found to be up-regulated in SCCHN and also the first protein to be targeted for antibody treatment (40). Three biopsies were identified as highly over-expressing EGFR in this study, which was further confirmed using q-PCR and immunohistochemistry. These data confirm that accurate mRNA expression data can be obtained from archived FFPE tumour samples that have been stored for up to at least 11 years.

$B C L 2 A 1$, a member of the BCL-2 family of anti-apoptotic genes was the gene with highest significance and a fold induction of 5.4 in tumours compared to controls. Another member of the family, BCL2, showed a 2-fold up-regulation that was not statistically significant due to over-expression in only a fraction of tumours, as previously reported by immunohistochemistry (41). Querying the Oncomine database of microarray expression profiles (42) supports our data of $B C L 2 A 1$ over-expression in SCCHN. Those data also suggested site-specific expression, with higher levels of $B C L 2 A 1$ found in laryngeal tumours than tumours of the oral cavity, oropharynx or hypopharynx and no correlation with stage or survival (43). BCL2Al is normally restricted to the haematopoietic compartment, but over-expression has been seen in a number of non-haematological malignancies including bladder cancer, skin cancer and melanomas (4446). The over-expression of $B C L 2 A 1$ in our samples did not seem to be due to inflammatory cells. Detection of BCL2A1 in $S C C H N$ cancer cell lines further shows the capability of SCCHN cells to express BCL2A1. To confirm that SCCHN tumours express the BCL2A1 protein, immunohistochemistry is needed, but could not be performed here due to lack of reliable antibodies. Previous studies have described the importance of other BCL2 family members in SCCHN $(41,47)$ and our data implicate $B C L 2 A 1$, which has an antiapoptotic function, as an important factor in tongue tumours.

Based on differences in survival, exposure to risk factors, and sex distribution, several authors have suggested that young adults with tongue tumours comprise a subgroup of patients with distinct internal and/or external factors for developing tumours $(13,48,49)$. However, only a few studies have been performed to explore differences between tumours 
A
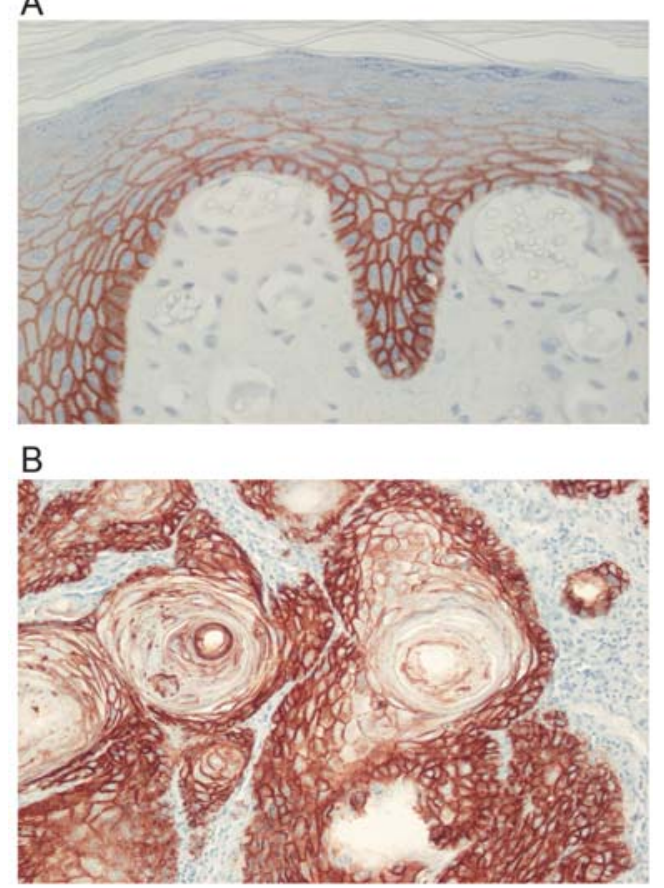

Figure 3. Confirmation of array data using immunohistochemistry. The same samples that were analyzed by q-PCR for $E G F R$ were also analyzed by immunohistochemical staining using an EGFR antibody (brown staining). Two representative samples are shown; one control sample (A) (magnification, $\mathrm{x} 40$ ), and one tumour sample over-expressing EGFR at the mRNA level (B) (magnification, x20).

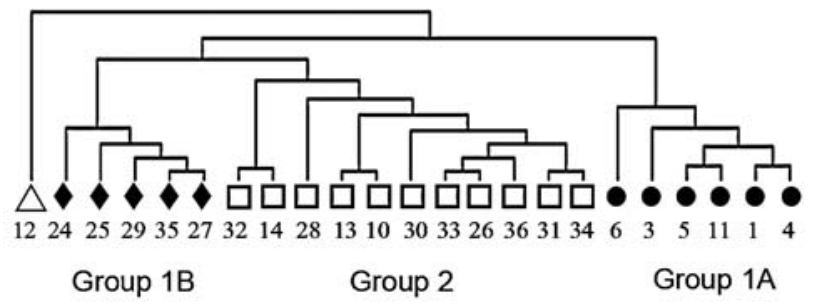

Figure 4. Unsupervised hierarchical clustering of cancer samples. All replicates were averaged and re-analyzed using hierarchical clustering. Cancer samples separated into three different groups. Circles, diamonds and squares represent group 1A, 1B and 2, respectively. One tumour biopsy did not cluster with the others and is represented by a triangle, number 12 . Tumour sample 9 which clustered with the controls is not shown.

from young and old patients at the molecular level. Infection with human papilloma viruses (HPV) has been suggested as a contributing factor to the increasing numbers of SCCHN in young people, but little evidence for this has been shown in young tongue cancer patients $(50,51)$. A trend towards silencing of p16 in young adults caused by DNA methylation in contrast to deletions in older patients was recently reported, whereas no significant difference in p16 expression was found (52). By investigating expression levels of 502 cancerrelated genes we sought to identify genes or pathways that could be important in development of tongue tumours in young adults. That none of the 502 genes, of which 126 were statistically different between cancer and control, were identified as statistically differentially expressed in tumours from young compared to old patients and that only three genes
Table IV. Two-fold filtered significantly differentially expressed genes.

A.

\begin{tabular}{llc}
\hline Gene symbol & Accession number & Avg. fold-change \\
\hline XRCC2 & NM_005431.1 & 5.0 \\
BRCA2 & NM_000059.1 & 4.9 \\
HMMR & NM_012485.1 & 3.6 \\
RECQL & NM_002907.2 & 2.8 \\
BLM & NM_000057.1 & 2.4 \\
LIG1 & NM_000234.1 & -2.0 \\
TFE3 & NM_006521.3 & -2.1 \\
COL1A1 & NM_000088.2 & -2.1 \\
PIM1 & NM_002648.2 & -2.2 \\
FGFR4 & NM_002011.2 & -2.2 \\
FGFR1 & NM_023110.1 & -2.2 \\
PURA & NM_005859.2 & -2.3 \\
TIAM1 & NM_003253.1 & -2.4 \\
ZNFN1A1 & NM_006060.2 & -2.7 \\
PPP2R1B & NM_002716.3 & -2.7 \\
RELA & NM_021975.1 & -2.7 \\
\hline
\end{tabular}

B.

\begin{tabular}{llc}
\hline Gene symbol & Accession number & Avg. fold-change \\
\hline MMP10 & NM_002425.1 & 3.3 \\
$F A N C G$ & NM_004629.1 & -2.1 \\
$C C N H$ & NM_001239.2 & -2.2 \\
BARD1 & NM_000465.1 & -2.5 \\
\hline
\end{tabular}

C.

\begin{tabular}{llc}
\hline Gene symbol & Accession number & Avg. fold-change \\
\hline LCN2 & NM_005564.2 & 2.1 \\
SERPINE1 & NM_000602.1 & -2.6 \\
PTGS2 & NM_000963.1 & -2.8 \\
\hline
\end{tabular}

were identified as differentially expressed at a level of $\geq 2$-fold, whereas many more genes were identified within different sub-groups of tumours irrespective of age, disagrees with the notion of a radical difference in pathobiology between the groups.

A prominent group of genes that separated patients into three clusters (1A, 1B and 2) are involved in DNA repair. Deficiencies in DNA repair pathways are strongly correlated with tumour formation (53). On the other hand, enhanced ability to repair DNA damage can be of benefit for the tumour, rendering it more resistant to treatment. For example, chemoresistance in women with relapsing ovarian cancer likely relies on increased efficiency in repairing DNA damage (54), and the levels of $E R C C 1$, which is involved in nucleotide excision repair, identifies a sub-group of oesophageal SCCHN patients who respond poorly to combined adjuvant therapy 
(55). Targeting a number of DNA repair proteins such as RAD51, XRCC4 and ATM has also been shown to increase radiation sensitivity in tumour cell lines (56-58). In our study, tumours could be sub-classified on the basis of expression of genes with roles in DNA repair and there was a numeric better therapeutic response to irradiation in patients with lowest expression of DNA repair genes (Group 1B), and poorer response in patients with highest expression (Group 1A).

Most carcinomas have a suppressed ability to repair or sense DNA damage in one or several pathways since both genomic instability and avoidance of apoptosis induced by DNA damage are hallmarks of cancer (59). Therefore, targeting a functional DNA repair pathway can have an exaggerated effect on tumour cells compared to normal cells where all other DNA repair pathways are still intact. This was illustrated by Farmer and colleagues, who showed that a cell line defective in BRCA1/2, involved in repair of doublestrand breaks, is sensitive to depletion of poly(ADP-ribose) polymerase PARP1, an enzyme involved in repair of single strand breaks (60). Based on these observations and our results, it could be hypothesised that group 1A patients would favour particularly from combining radiotherapy with suppression of DNA repair. The majority of the deregulated DNA repair genes in our study are involved in homologous recombination (HR) repair of double-strand breaks. Thus, the ability to inhibit this pathway may have therapeutic benefit for this specific group of patients and a larger study group is warranted to confirm these results.

In conclusion, we have demonstrated the applicability of expression profiling applied to formalin-fixed and paraffinembedded samples. Results from analysis of 502 selected cancer related genes do not support a significant difference for SCC of the tongue in young patients. The finding that a subset of SCCHN expressed high levels of DNA repair genes in association with impaired therapeutic response to radiation suggests that these genes could represent predictive biomarkers for therapy response and also provide a novel mechanism for improving therapy response by targeting homologous recombination repair of double-strand DNA breaks in this group of patients.

\section{Acknowledgements}

This study was supported by grants from Lion's Cancer Research Foundation, Umeå University, the Swedish Cancer Society contract number 08 0371, the Kempe foundation and the National Board of Health and Welfare.

\section{References}

1. Blot WJ, McLaughlin JK, Winn DM, et al: Smoking and drinking in relation to oral and pharyngeal cancer. Cancer Res 48: 3282-3287, 1988.

2. Sturgis EM, Wei Q, and Spitz MR: Descriptive epidemiology and risk factors for head and neck cancer. Semin Oncol 31: 726-733, 2004.

3. Jovanovic A, Schulten EA, Kostense PJ, Snow GB and van der Waal I: Tobacco and alcohol related to the anatomical site of oral squamous cell carcinoma. J Oral Pathol Med 22: 459-462, 1993.

4. Mellin H, Friesland S, Lewensohn R, Dalianis T and MunckWikland E: Human papillomavirus (HPV) DNA in tonsillar cancer: clinical correlates, risk of relapse, and survival. Int $\mathbf{J}$ Cancer 89: 300-304, 2000.
5. Rautava J, Luukkaa M, Heikinheimo K, Alin J, Grenman R and Happonen RP: Squamous cell carcinomas arising from different types of oral epithelia differ in their tumor and patient characteristics and survival. Oral Oncol 43: 911-919, 2007.

6. Ziober AF, Patel KR, Alawi F, et al: Identification of a gene signature for rapid screening of oral squamous cell carcinoma. Clin Cancer Res 12: 5960-5971, 2006.

7. Annertz K, Anderson H, Biorklund A, et al: Incidence and survival of squamous cell carcinoma of the tongue in Scandinavia, with special reference to young adults. Int J Cancer 101: 95-99, 2002.

8. Macfarlane GJ, Boyle P, and Scully C: Oral cancer in Scotland: changing incidence and mortality. BMJ 305 1121-1123, 1992.

9. Plesko I, Macfarlane GJ, Evstifeeva TV, Obsitnikova A and Kramarova E: Oral and pharyngeal cancer incidence in Slovakia 1968-1989. Int J Cancer 56: 481-486, 1994.

10. Schantz SP and Yu GP: Head and neck cancer incidence trends in young Americans, 1973-1997, with a special analysis for tongue cancer. Arch Otolaryngol Head Neck Surg 128: 268-274, 2002.

11. McGregor GI, Davis N and Robins RE: Squamous cell carcinoma of the tongue and lower oral cavity in patients under 40 years of age. Am J Surg 146: 88-92, 1983.

12. Sarkaria JN and Harari PM: Oral tongue cancer in young adults less than 40 years of age: rationale for aggressive therapy. Head Neck 16: 107-111, 1994.

13. Garavello W, Spreafico R and Gaini RM: Oral tongue cancer in young patients: a matched analysis. Oral Oncol 43: 894-897, 2007.

14. Atula S, Grenman R, Laippala P and Syrjanen S: Cancer of the tongue in patients younger than 40 years. A distinct entity? Arch Otolaryngol Head Neck Surg 122: 1313-1319, 1996.

15. Pitman KT, Johnson JT, Wagner RL and Myers EN: Cancer of the tongue in patients less than forty. Head Neck 22: 297-302, 2000.

16. Verschuur HP, Irish JC, O'Sullivan B, Goh C, Gullane PJ and Pintilie M: A matched control study of treatment outcome in young patients with squamous cell carcinoma of the head and neck. Laryngoscope 109: 249-258, 1999.

17. Akervall JA, Michalides RJ, Mineta $\mathrm{H}$, et al: Amplification of cyclin D1 in squamous cell carcinoma of the head and neck and the prognostic value of chromosomal abnormalities and cyclin D1 overexpression. Cancer 79: 380-389, 1997.

18. Geisler SA, Olshan AF, Weissler MC, et al: p16 and p53 protein expression as prognostic indicators of survival and disease recurrence from head and neck cancer. Clin Cancer Res 8: 3445-3453, 2002.

19. Laimer K, Spizzo G, Gastl G, et al: High EGFR expression predicts poor prognosis in patients with squamous cell carcinoma of the oral cavity and oropharynx: a TMA-based immunohistochemical analysis. Oral Oncol 43: 193-198, 2007

20. Bittner M, Meltzer P, Chen Y, et al: Molecular classification of cutaneous malignant melanoma by gene expression profiling. Nature 406: 536-540, 2000.

21. Golub TR, Slonim DK, Tamayo P, et al: Molecular classification of cancer: class discovery and class prediction by gene expression monitoring. Science 286: 531-537, 1999.

22. Weigelt B, Glas AM, Wessels LF, Witteveen AT, Peterse JL and van't Veer LJ: Gene expression profiles of primary breast tumors maintained in distant metastases. Proc Natl Acad Sci USA 100: 15901-15905, 2003.

23. Belbin TJ, Singh B, Barber I, et al: Molecular classification of head and neck squamous cell carcinoma using cDNA microarrays. Cancer Res 62: 1184-1190, 2002.

24. Masuda N, Ohnishi T, Kawamoto S, Monden M and Okubo K: Analysis of chemical modification of RNA from formalin-fixed samples and optimization of molecular biology applications for such samples. Nucleic Acids Res 27: 4436-4443, 1999.

25. von Ahlfen S, Missel A, Bendrat K and Schlumpberger M: Determinants of RNA quality from FFPE samples. PLoS ONE 2: e1261, 2007.

26. Clark-Langone KM, Wu JY, Sangli C, et al: Biomarker discovery for colon cancer using a 761 gene RT-PCR assay. BMC Genomics 8: 279, 2007.

27. Penland SK, Keku TO, Torrice C, et al: RNA expression analysis of formalin-fixed paraffin-embedded tumors. Lab Invest 87: 383-391, 2007.

28. Bibikova M, Talantov D, Chudin E, et al: Quantitative gene expression profiling in formalin-fixed, paraffin-embedded tissues using universal bead arrays. Am J Pathol 165: 1799-1807, 2004. 
29. Fan JB, Yeakley JM, Bibikova M, et al: A versatile assay for high-throughput gene expression profiling on universal array matrices. Genome Res 14: 878-885, 2004.

30. Tusher VG, Tibshirani R and Chu G: Significance analysis of microarrays applied to the ionizing radiation response. Proc Natl Acad Sci USA 98: 5116-5121, 2001

31. Specht K, Richter T, Muller U, Walch A and Hofler MW: Quantitative gene expression analysis in microdissected archival tissue by real-time RT-PCR. J Mol Med 78: B27, 2000.

32. Beskow C, Agren-Cronqvist AK, Granath F, Frankendal B and Lewensohn R: Pathologic complete remission after preoperative intracavitary radiotherapy of cervical cancer stage Ib and IIa is a strong prognostic factor for long-term survival: analysis of the Radiumhemmet data 1989-1991. Int J Gynecol Cancer 12: 158-170, 2002

33. Friesland S, Fernberg JO, Lundell G, Munck-Wikland E, Strander H and Lewensohn R: Prognostic impact of complete remission after preoperative irradiation of tonsillar carcinoma: a retrospective analysis of the radiumhemmet data, 1980-1995. Int J Radiat Oncol Biol Phys 45: 1259-1266, 1999.

34. Eisen MB, Spellman PT, Brown PO and Botstein D: Cluster analysis and display of genome-wide expression patterns. Proc Natl Acad Sci USA 95: 14863-14868, 1998.

35. Kornberg LJ, Villaret D, Popp M, et al: Gene expression profiling in squamous cell carcinoma of the oral cavity shows abnormalities in several signaling pathways. Laryngoscope 115: 690-698, 2005.

36. Llewellyn CD, Linklater K, Bell J, Johnson NW and Warnakulasuriya KA: Squamous cell carcinoma of the oral cavity in patients aged 45 years and under: a descriptive analysis of 116 cases diagnosed in the South East of England from 1990 to 1997. Oral Oncol 39: 106-114, 2003.

37. Gutschalk CM, Herold-Mende CC, Fusenig NE and Mueller MM: Granulocyte colony-stimulating factor and granulocytemacrophage colony-stimulating factor promote malignant growth of cells from head and neck squamous cell carcinomas in vivo. Cancer Res 66: 8026-8036, 2006.

38. Ruokolainen H, Paakko P and Turpeenniemi-Hujanen T: Expression of matrix metalloproteinase-9 in head and neck squamous cell carcinoma: a potential marker for prognosis. Clin Cancer Res 10: 3110-3116, 2004

39. Shi Z and Stack MS: Urinary-type plasminogen activator (uPA) and its receptor (UPAR) in squamous cell carcinoma of the oral cavity. Biochem J 407: 153-159, 2007.

40. Mehra R, Cohen RB and Harari PM: EGFR inhibitors for the treatment of squamous cell carcinoma of the head and neck. Curr Oncol Rep 10: 176-184, 2008.

41. Hotz MA, Bosq J, Zbaeren P, et al: Spontaneous apoptosis and the expression of $\mathrm{p} 53$ and $\mathrm{Bcl}-2$ family proteins in locally advanced head and neck cancer. Arch Otolaryngol Head Neck Surg 125: 417-422, 1999.

42. Rhodes DR, Yu J, Shanker K, et al: ONCOMINE: a cancer microarray database and integrated data-mining platform. Neoplasia 6: 1-6, 2004.

43. Chung CH, Parker JS, Karaca G, et al: Molecular classification of head and neck squamous cell carcinomas using patterns of gene expression. Cancer Cell 5: 489-500, 2004.

44. Kathpalia VP, Mussak EN, Chow SS, et al: Genome-wide transcriptional profiling in human squamous cell carcinoma of the skin identifies unique tumor-associated signatures. J Dermatol 33: 309-318, 2006.
45. Kim JK, Kim KD, Lee E, et al: Up-regulation of Bfl-1/A1 via NF-kappaB activation in cisplatin-resistant human bladder cancer cell line. Cancer Lett 212: 61-70, 2004.

46. Torikai H, Akatsuka Y, Yatabe Y, et al: Aberrant expression of BCL2A1-restricted minor histocompatibility antigens in melanoma cells: application for allogeneic transplantation. Int J Hematol 87: 467-473, 2008.

47. Mallick S, Patil R, Gyanchandani R, et al: Human oral cancers have altered expression of Bcl-2 family members and increased expression of the anti-apoptotic splice variant of Mcl-1. J Pathol 217: 398-407, 2009.

48. Koch WM, Lango M, Sewell D, Zahurak M and Sidransky D: Head and neck cancer in nonsmokers: a distinct clinical and molecular entity. Laryngoscope 109: 1544-1551, 1999.

49. O'Regan EM, Timon C, Sheils O, Codd M, O'Leary JJ and Toner M: Squamous cell carcinoma of the head and neck in young Irish adults. Br J Oral Maxillofac Surg 44: 203-206, 2006.

50. Liang XH, Lewis J, Foote R, Smith D and Kademani D: Prevalence and significance of human papillomavirus in oral tongue cancer: the Mayo Clinic experience. J Oral Maxillofac Surg 66: 1875-1880, 2008

51. Ringstrom E, Peters E, Hasegawa M, Posner M, Liu M and Kelsey KT: Human papillomavirus type 16 and squamous cell carcinoma of the head and neck. Clin Cancer Res 8: 3187-3192, 2002.

52. O'Regan EM, Toner ME, Finn SP, et al: p16(INK4A) genetic and epigenetic profiles differ in relation to age and site in head and neck squamous cell carcinomas. Hum Pathol 39: 452-458, 2008.

53. Khanna KK and Jackson SP: DNA double-strand breaks: signaling, repair and the cancer connection. Nat Genet 27: 247-254, 2001.

54. Wynne P, Newton C, Ledermann JA, Olaitan A, Mould TA and Hartley JA: Enhanced repair of DNA interstrand crosslinking in ovarian cancer cells from patients following treatment with platinum-based chemotherapy. Br J Cancer 97: 927-933, 2007.

55. Warnecke-Eberz U, Metzger R, Miyazono F, et al: High specificity of quantitative excision repair cross-complementing 1 messenger RNA expression for prediction of minor histopathological response to neoadjuvant radiochemotherapy in esophageal cancer. Clin Cancer Res 10: 3794-3799, 2004.

56. Hickson I, Zhao Y, Richardson CJ, et al: Identification and characterization of a novel and specific inhibitor of the ataxiatelangiectasia mutated kinase ATM. Cancer Res 64: 9152-9159, 2004.

57. Jones KR, Gewirtz DA, Yannone SM, et al: Radiosensitization of MDA-MB-231 breast tumor cells by adenovirus-mediated overexpression of a fragment of the XRCC4 protein. Mol Cancer Ther 4: 1541-1547, 2005.

58. Sak A, Stueben G, Groneberg M, Bocker W and Stuschke M: Targeting of Rad51-dependent homologous recombination: implications for the radiation sensitivity of human lung cancer cell lines. Br J Cancer 92: 1089-1097, 2005.

59. Hanahan D and Weinberg RA: The hallmarks of cancer. Cell 100: 57-70, 2000

60. Farmer $\mathrm{H}, \mathrm{McCabe} \mathrm{N}$, Lord $\mathrm{CJ}$, et al: Targeting the DNA repair defect in BRCA mutant cells as a therapeutic strategy. Nature 434: 917-921, 2005. 